\title{
Hesse election brings nuclear relief by a narrow margin
}

Munich

A NARROW victory by West Germany's ruling conservative coalition in the 5 April state elections in Hesse has removed one of the major obstacles to the coalition's nuclear policy.

The victory for the coalition - composed of the Christian Democrats (CDU) and the Free Democrats (FDP) - assures a conservative majority for the foreseeable future in the Bundesrat, the upper house of the federal parliament. Composed of representatives of the state (Land) governments, the Bundesrat has the power of veto over any laws, such as those governing the nuclear industry, that affect the interest of the states. By winning most of the five state elections being held this year in West Germany, the Social Democrats (SPD) would have threatened to tie the hands of the Kohl government.

The Hesse election, in which the CDU and FDP won a total of 56 seats in the 110 seat state parliament, ended an uninterrupted 40-year span of SPD rule in heavily industrialized Hesse. The latest SPD government, a so-called "red-green" coalition with the Green party, collapsed in February over a dispute involving the processing of plutonium at the nuclear fuel manufacturer Alkem. In March, the government of Hesse filed suit in the German Supreme Court at Karlsruhe challenging the federal government's jurisdiction over the plutonium industry and calling for a halt to the handling of plutonium at Alkem. The new MinisterPresident of Hesse, Walter Wallmann (CDU), has announced that he will withdraw the suit as soon as he takes office.

Wallmann's return to Hesse (he served as mayor of Frankfurt from 1977 until 1986) was greeted with a sigh of relief from industry, which had feared that a redgreen coalition with a stronger Green representation would mean stricter and costlier environmental controls.

Perhaps most significant for the West German political scene was the collapse of the Social Democrats. They lost voters both to the CDU and to the Greens, whose share of the vote grew to a solid 9.4 per cent. This loss by the SPD in a state it has long controlled has been attributed to its attempt to please Green-leaning voters with a strong pro-environment policy without doing enough to retain its traditional base of unionized workers. The loss has also been attributed to the recent resignation of long-time party leader, former Chancellor Willy Brandt.

The Greens, the environmental party whose inclusion in the red-green coalition in 1985 marked a turning point in German politics, now find themselves once again in the opposition. A demoralized Karin Guder, head of the Greens' Hessian party office in Frankfurt, said that the party's "only chance" now of influencing policy is through public information and citizen initiatives. The 3.5 per cent growth in support for the Greens compared with the last election is "small consolation" for the loss of parliamentary responsibility.

But the election results are less sourly regarded by "fundamentalist" Greens, who had disapproved of entering into the coalition in the first place

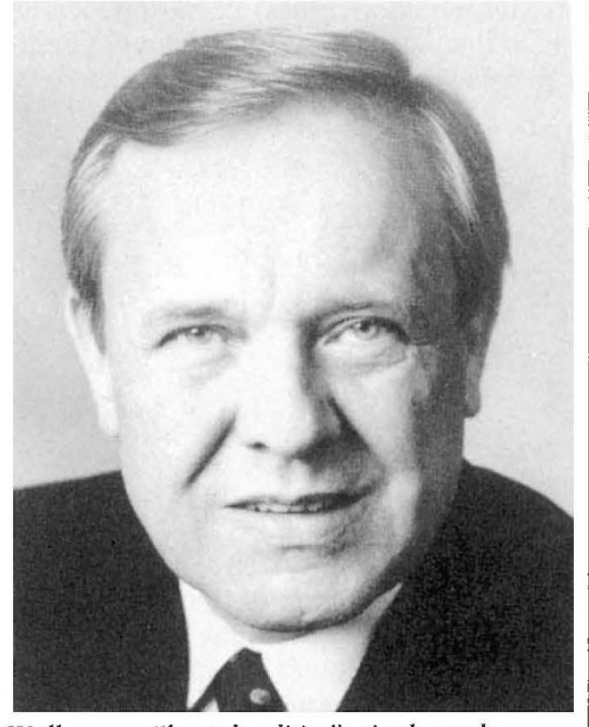

Wallman - "brutal politics" win through.

Jutta Ditfurth, leader of the so-called "eco-socialist" wing of the party in Frankfurt, said that it is preferable to carry out "radical reform politics" while outside the ruling coalition, especially when there is an SPD minority government, as was the case before the red-green coalition was formed. Despite their strong showing in the elections, the Greens will be hardpressed to counter what Ditfurth called the "brutal politics" of Wallmann.

In becoming Hessian Minister-President, Wallmann vacates the post of federal Environment Minister. His replacement will be Klaus Töpfer (CDU), who had been Environment Minister of the state of Rhineland-Palatinate since 1985. Töpfer is expected to follow the nuclear policies of his predecessor.

According to a source in the RhinelandPalatinate Environment Ministry, Töpfer's approval of a gradual "renunciation" of nuclear energy merely reflects the CDU nuclear programme, which calls for the continued reliance on nuclear energy until alternative energy sources have been found. The conservative Frankfurter Allgemeine Zeitung newspaper called Töpfer a "master of damage control".

Steven Dickman
New research centre London

THE General Electric Company (GEC) is to build a new research centre at the Cambridge science park. An eight-acre site has been acquired from Trinity College, the science park trustees.

The unit will be completed in three years' time, says Dr John Williams, managing director of GEC Research, and will create 600 jobs (500 for graduates).

In moving to Cambridge, GEC acknowledges the success of the science park as a centre of excellence and the benefit of strengthening their links with the university. This development is part of the fourth of five phases of growth at the park.

The centre will have a multidisciplinary approach with research initiatives in areas such as microelectronics as well as information technology and software, and is expected to provide technological advances for the company's existing production units. S.H.

\section{Canadian Ariane launch London}

Telesat's next communications satellites, Anik E1 and Anik E2, will be launched in 1990 , and will be the first communications satellites launched by Arianespace. A launch agreement was signed by Eldon Thompson, President of Telesat Canada, and Frederic D'Allest, chairman of Arianespace, on 10 April. Ariane is one of the most powerful European launch vehicles and places satellites directly into geostationary orbits. "The dedicated launch will ensure that each satellite will have an operational life of ten years" said Thompson. Telesat now has five Anik satellites in orbit, more than any other domestic satellite company. The new satellites are designed to meet their communications requirements until at least the year 2000.

S.H.

\section{Rees to be MRC secretary}

\section{London}

DR David Allan Rees will be the first nonmedic to be secretary of the Medical Research Council (MRC) when he succeeds Sir James Gowans on 1 October this year.

Rees, whose research interests have been in the structure and biochemistry of polysaccharides, is at present director of the MRC's National Institute for Medical Research and visiting professor in biophysics at King's College, London. He has instigated a major reorganization at the institute and created an MRC Collaborative Centre where council and industrial scientists can work side by side. His successor has yet to be selected.

It is understood that Gowans will continue to organize the MRC-financed AIDS (acquired immune deficiency syndrome) programme at least until the end of the year. 